\title{
A Modern városok program jelentősége a hazai városfejlődésben
}

\section{The Modern Cities Programme in Hungarian urban development}

\author{
FEKETE DÁVID
}

FEKETE Dávid: egyetemi adjunktus, Széchenyi István Egyetem, Regionális-tudományi és Közpolitikai Tanszék; 9026 Győr, Egyetem tér 1.; fdavid@sze.hu; https:// orcid.org/0000-0002-8097-2496

KULCSSZAVAK: városfejlesztés; Modern városok program; városfejlesztési rezsim; újraiparosítás; gazdaságfejlesztés

ABSZTRAKT: Magyarország kormánya 2015-ben nagyszabású városfejlesztési projektcsomagot indított el Modern városok program címmel. A fejlesztésekről a 23 megyei jogú város polgármesterei külön-külön találkozókon egyeztek meg a kormányfővel 2015 és 2017 között. A program teljes költségvetése mintegy 3400 milliárd forint, az abban szereplő fejlesztések a kormányzati tervek szerint 2022-ig befejeződnek. A programot elemző kutatásban az alábbi szempontok szerint vizsgáltuk a fejlesztési programot: a program európai és hazai területfejlesztési politikában betöltött szerepe, a központi költségvetésre és az önkormányzati forrásokra gyakorolt hatásai, a gazdaságfejlesztéshez és újraiparosításhoz való hozzájárulása, a program mint új városfejlesztési rezsim.

A hazai területfejlesztés elmúlt évszázadában nem találtunk olyan városfejlesztési programot, mely filozófiájában és költségvetési volumenében hasonlítható lenne a Modern városok programhoz. A program előképe elsősorban az 1960-as években megjelenő, de napjainkban is gyakran alkalmazott francia etatista-dirigista megközelítés, hiszen jelentős hasonlóságot mutatnak az alkalmazott eszközök és módszerek, így pl. a tervszerződések rendszere, a központi finanszírozás és döntéshozatal. A program újszerủ városfejlesztési rezsimként történő értelmezése ugyanakkor nem bizonyított: az ehhez szükséges, széles körű társadalmi bevonás alapján közösen kialakított fejlesztési célkitűzések nem voltak tapasztalhatók. A program fontos fókusza a gazdaságfejlesztés: gyakorlatilag valamennyi város érintett az iparfejlesztéssel, gazdaságfejlesztéssel kapcsolatos intézkedésekben. Az elmúlt évek megyei jogú városokat érintő kormányzati döntései közül a program meghatározó fejlesztési forrásokat biztosít az érintettek számára, városonként átlagosan kb. 150 milliárd Ft értékben valósulnak meg fejlesztések.

Dávid FEKETE: assistant professor, Department for Regional Sciences and Public Policy, Széchenyi István University; Egyetem tér 1., H-9026 Györ, Hungary; fdavid@sze.hu; https://orcid.org/0000-0002-8097-2496

KEYWORDS: urban development; Modern Cities Programme; urban development regime; reindustrialisation; economic development

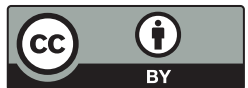


ABSTRACT: In 2015, the Hungarian government launched a major urban development project package called Modern Cities Programme. The mayors of the 23 cities with county rights agreed on the projects in separate meetings with the head of government between 2015 and 2017. The total budget of the programme is about HUF 3400 billion, and according to the government's plans, the developments will be completed by 2022. The development programme was analysed in terms of its contribution to European and national spatial development policy, its impact on the central budget and sources of local government, its contribution to economic development and reindustrialisation, and its suitability as a blueprint for a new urban development regime.

On the basis of the research results, it can be said that in the last century of Hungarian spatial development there is no urban development programme whose philosophy and budget volume is comparable to that of Modern Cities. Similar project characteristics were only found in the French state-directed programmes that emerged in the 1960s. They are still widely found today because they are very similar as to their instruments and methods, such as the system of design contracts, the importance of central funding and decision-making. However, the interpretation of the programme as a new urban regime went too far: The development goals formulated jointly on the basis of far-reaching citizens' participation showed no immediately identifiable results. As one of the programme's priorities is economic growth, practically all cities are involved in industrial and economic development measures. Among the recent government decisions taken on behalf of cities with county rights, the programme provides crucial development resources for the 23 cities, averaging HUF 150 billion per city.

The central budget for the implementation of the programme in 2015 included HUF 25 billion, HUF 50 billion in 2016, HUF 152 billion in 2017 and HUF 150 billion in 2018. These amounts represent $0.41 \%$ of GDP in 2017 and $0.37 \%$ in 2018. The financial data suggest that, contrary to some opinions, funding of the programme was sufficient in spite of its disproportionate size. In conjunction with this 3400 billion HUF programme, the Territorial and Settlement Development Operational Programme (TOP) provides approximately HUF 400 billion for other or related developments of the 23 cities. It is worth noting that the volume of government consolidated debt from the 23 cities corresponds to the entire volume of urban development resources of the Operational Programme. Against this background, the government subsidies made available for cities with county rights are significant.

\section{Bevezetés, vizsgálati keretek és alkalmazott módszerek}

A Gróf Bethlen István Kutatóközpontban végrehajtott első kutatási program témája a Modern városok program elemzése volt. Magyarország kormánya 2015 márciusában Sopronban hirdette meg a Modern városok programot, az egyeztetéssorozat 2017 májusában Hódmezővásárhelyen zárult, a Miniszterelnökség összegzése szerint a megyei jogú városok összesen 3400 milliárd forintnyi fejlesztési forrásra számíthatnak a következő években. A kutatócsoport ${ }^{1}$ meggyőződése volt, hogy egy ekkora horderejü városfejlesztési programot érdemes tudományos kérdésfelvetéssel elemezni, s azért is különösen indokolt a tudományos vizsgálódás, mert az elmúlt években nem volt ilyen volumenü hazai településfejlesztési törekvés.

A kutatási program célja volt, hogy elemezze és értékelje a Modern városok programot. Kiemelten fókuszáltunk a program európai és hazai területfejlesztési politikában betöltött szerepére. A kutatás hipotézise szerint a Modern városok program volumene és megvalósításának módja egyedülálló a hazai vá- 
rosfejlesztési programok történetében, mely hipotézist elsősorban a 20. századi magyar városfejlesztési programokkal való összehasonlítással teszteltük. Szintén kérdés volt, hogy rendelkezik-e olyan attribútumokkal a program, mely új városfejlesztési rezsimet eredményezett. A program finanszírozásával kapcsolatban annak központi költségvetésre és önkormányzati forrásokra gyakorolt hatásait elemeztük, s ehhez kapcsolódva áttekintettük a megyei jogú városok finanszírozásának változását a 2010 utáni időszakban. A kutatás vizsgálta, hogy a meghirdetett fejlesztések mennyiben szolgálják a hazai megyei jogú városok európai városversenyben meglévő pozícióinak erősítését, mennyiben járulnak hozzá azok fenntartható fejlődéséhez. Ehhez kapcsolódva kiemelt vizsgálati terület volt a Modern városok program gazdaságfejlesztéshez és újraiparosításhoz való hozzájárulása.

A kutatás keretében feldolgoztuk a kapcsolódó hazai és nemzetközi szakirodalmat, elvégeztük a 23 várossal megkötött megállapodás kvalitatív és kvantitatív szövegelemzését, áttekintettük a hozzáférhető kormányzati háttéranyagokat, kormányrendeleteket, költségvetési törvényeket. Jelen tanulmány a kutatás legfontosabb megállapításait, eredményeit összegzi, így a kutatásösszegző cikk műfaji sajátosságaival, továbbá korlátaival rendelkezik. ${ }^{2}$

\section{A program helye a hazai és az európai területfejlesztési politikában}

A regionális tudományokban a városi társadalmi-gazdasági folyamatok kutatása nagy népszerűségnek örvend. Egyrészt az Európai Unió területfejlesztési politikája, másrészt a városi gazdaság megújításával foglalkozó politikai beavatkozások (pl. növekedési pólus, iparági körzetek stb.) terelték a tudományág képviselőinek figyelmét az urbánus szerveződések fontosságára. A városok funkcióik szerinti csoportosításakor fontos hangsúlyozni, hogy napjainkban, a globalizált világ urbanizációjának korában a városok egy része „kilépett” a nemzeti városrendszerből, s nemzetközi szintü összekapcsolódásukból globális városhálózat alakult ki (Enyedi 2012). Ez a megállapítás azon megyei jogú városainkra is vonatkozhat (pl. Győr és Kecskemét), melyek elsősorban a multinacionális vállalatok fontos telephelyeként be tudtak kapcsolódni a globális termelési láncokba (a BMW-gyár letelepedésével Debrecen is csatlakozik a jövőben ezekhez a városokhoz). A hazai térségszervezés szempontjából fontos megállapítás, hogy a város-falu viszonyrendszer több szempontból is eltér a korábban megszokottól: a falvak napjainkban inkább a városokhoz integrálódott vidéki településként jellemezhetők, melyek közvetlenül hozzájárulnak az egész várostérség fejlődéséhez. Az erős városok pedig egyre inkább meghatározzák vidéki környezetüket (Faragó 2006). Ez a jelenség a megyei jogú városaink jelentős részében megfigyelhető. A nagyvárosi 
kormányzás újabb hulláma meghaladta a korábbi közigazgatási-területi tervezési szempontokat, s mint a gazdaságfejlesztési politika mechanizmusa lépett színre (Somlyódyné Pfeil 2011), a gyakorlatban sok új eszköz is megjelent a 23 megyei jogú városban.

A területi versenyben a szereplők fő eszköze olyan helyi gazdaságfejlesztési elképzelések kidolgozása és végrehajtása, melynek révén a jövedelemtermelő képességet növelni tudó üzleti környezet jön létre, s a jövőkép ismeretében ebbe a folyamatba a helyi vállalkozások minél szélesebb köre és a lakosság is be tud kapcsolódni. A területi egységek közötti verseny hasonló fejlettségű városok/régiók között zajlik, melyek egyazon hierarchiaszinten vannak (így pl. agrárrégiók, ipari körzetek, logisztikai-pénzügyi központok). A verseny ugyanakkor nem nulla összegű játszma, a versenytársak nem (csak) egymás rovására tudnak működni, sőt pl. infrastruktúra-fejlesztésben sok esetben gyümölcsözőbb mindegyikük számára az együttműködés (Lengyel 2010). Önmagában az a jelenség, hogy a kormányzat egyszerre kívánja fejleszteni az egy hierarchiaszinten levő városokat, még nem jelenti azt, hogy szükségszerüen egymást kioltó fejlesztésekről lenne szó. Faragó (2016) felhívja a figyelmet az európai uniós támogatási rendszerekkel kapcsolatban arra a helyzetre, miszerint a területi kohézió helyett egyre inkább a versenyképesség-alapú támogatáspolitika kerül előtérbe. Ez pedig hátrányosan érinti a kohéziós országokat, melyeknek fontos szerepe van a fóvárosokon kívüli térségek fejlesztésében, az agglomerációs hatások katalizálásában.

Napjaink városfejlesztési folyamataiban egyre gyakrabban megfigyelhetők az érintett szereplők együttműködései. A sokszereplős városfejlesztést célzó együttmúködések a szakirodalomban a városrezsim elnevezést bírják, melynek alapjait az 1980-as évek USA-beli folyamatai jelentik (vö. Stone 1989; Stone, Sanders 1987). Az elmúlt évek több kutatási eredménye (Fekete 2017b; Pálné Kovács 2010; Somlyódyné Pfeil 2014) is bizonyítja, hogy a városok fejlődésében a governance-szerü együttmüködések fontos szerepet játszanak, s a stakeholderek új típusú együttműködései, azok intézményesített rendszere pozitív hatást gyakorol a városfejlesztési folyamatokra. A hazai empirikus vizsgálatok legutóbbi eredményei gyakorta hívják fel a figyelmet a városi stakeholderek bevonásának elmaradására, illetve azok városfejlesztési folyamatokba való bekapcsolódásának gyengeségeire (Bajmócy et al. 2016; Bajmócy, Gébert, Málovics 2017; Füzér 2017; Mezei 2016; Pálné Kovács, Mezei 2016), bár ellenpéldákat is feltártak (Fekete 2018b).

A napjainkban zajló gazdasági folyamatok újra ráirányították a figyelmet az iparra. Az újraiparosodás azt a tendenciát fejezi ki, miszerint a technológiai fejlődés révén részben a feldolgozóipar részét képező új ágazatok jelentek meg (pl. infokommunikáció), továbbá területi szempontból vizsgálva pl. a volt szocialista országokban a dezindusztrializációs folyamatok révén eltűntek az alacsony termelékenységű ágazatok, s a helyükbe általában multinacionális vállalatok működőtőke-befektetései révén magas hozzáadott értéket képviselő ipari 
tevékenység került (Barta, Czirfusz, Kukely 2008). Az újraiparosodás közép-európai lehetőségeit vizsgálva Lux (2017) megadja az újraiparosítás fogalmát, mely a szerkezetátalakítási folyamatok aktív formálásában gyökerezik. Közvetlen értelemben a vállalati környezet fejlesztését (telephelyek és támogató intézmények létrehozása és fejlesztése) értjük alatta, közvetett értelemben az ipar versenyképességét növelő térségi tényezőkínálat és az üzleti környezet innovatív fejlődését a társadalmi tőke és a térségi tudásbázis folyamatos fejlesztésével és megújításával.

A Modern városok program készítői a hazai településhálózat 23 megyei jogú városát választották ki a kormányzati retorikában gyakran „legnagyobb magyar vidékfejlesztési programként" említett fejlesztési koncepció kedvezményezettjének. E térségi központokban mintegy 2 millióan élnek, további 1 millióan pedig közvetlen vonzáskörzetükben, így a program hazánk lakosságának harmadát közvetlenül érinti. Ahhoz, hogy a 3400 milliárd Ft-os fejlesztési csomagot elhelyezhessük a hazai területfejlesztési politika elmúlt száz évében, érdemes egy pillantást vetni a hazai városközpontok kialakulásának összetett folyamatára.

Rechnitzer (2019) elemzésében rámutat arra, hogy a városok településhálózatban elfoglalt helyét nagyban befolyásolja azok népességszáma és az általuk betöltött városi funkciók jelentősége. A városok mint hálózati csomópontként értelmezhető központi helyek meghatározó népességgel bírnak, funkcióikat pedig közigazgatási határaikon átnyúló vonzáskörzetükben gyakorolják, térformáló erejük van. A hazai szakirodalom Magyarországon az 50000 lakosúnál nagyobb településeket tekinti nagyvárosnak. Noha több megyei jogú város (Dunaújváros, Nagykanizsa, Hódmezővásárhely, Salgótarján, Szekszárd) lélekszáma nem éri el ezt a határt, sokan közülük megyeszékhelyként jelentős térségszervező erőt fejtenek ki, továbbá a megyei jogú városi cím birtokosaként is bekerültek a városfejlesztési programba. Ma tehát 23 kiemelt várost tart számon a kormány mint különösen fejlesztendő vidéki térségszervező központot.

A magyar településfejlesztési gyakorlatban mindig is voltak törekvések a vidéki központok kategorizálására, differenciált fejlesztésére. Hazánk településhálózata magán viseli az elmúlt száz év történelmi viszontagságait. Az Osztrák-Magyar Monarchia idején a Kárpát-medencében több olyan nagyváros létezett (pl. Kolozsvár, Kassa), mely térségszervezési szempontból ellensúlyozta Budapest fővárosként kifejtett szerepét. A trianoni békediktátumot követően sok nagyvárosunk a határon túli területeken ragadt, s ez igaz volt a trianoni Magyarország területén maradó néhány nagyobb városunk természetes vonzáskörzetére is (pl. Debrecen, Győr, Pécs). Noha 1938-tól az országgyarapodások rövid időszakában a törvényhatósági jogú városok száma megduplázódott, 1947 után ismét visszatért a magyar településhálózat aránytalanul nagy főváros-centrikussága, melyet a Nagy-Budapest koncepció 1950-es évekbeli megvalósítása tetézett (Hajdú 1993, 2001). A második világháborút követő időszakban a városok betagozódtak a megyei tanácsok alá, majd 1954-ben 
Debrecent, Miskolcot, Szegedet és Pécset megyei jogú városi rangra emelték, az elnevezést 1971-ben megyei városra változtatták, a városok körét Győrrel bővítették. A listára 1989-ben Kecskemét, Nyíregyháza és Székesfehérvár is felkerült. A rendszerváltozást követően az ún. első önkormányzati törvény értelmében az elnevezés ismételten megyei jogú városra módosult, s azt minden 50000 főnél nagyobb lélekszámú település megkapta, így 21 megyei jogú város működött 1990-től. 1994-ben Szekszárd, majd 2006-ban Érd is - pályázat útján - elnyerte a címet (Rechnitzer 2019).

A kutatás során áttekintettük az elmúlt száz év hazai területi politikájának fejlesztési programjait, s kijelenthetjük, hogy nem található olyan nagyságrendű, a kiemelt térségszervező központokat tudatosan támogatni kívánó városfejlesztési intézkedéssorozat, mint a Modern városok program. Ráadásul a várakozások szerint a fejlesztések az egyes városokat sokkszerüen meglendíthetik, s ezáltal is megújulhatnak és gyarapodhatnak a városi-térségi funkciók (Rechnitzer 2019).

Érdemes vetni egy pillantást az európai térre! A kutatás során feltártuk azokat a kapcsolódási pontokat, melyek a Modern városok program hasonlóságait mutatják az európai területfejlesztési folyamatokkal. Bajmócy (2018) elemzése nyomán a Modern városok program leginkább a helyi gazdaságfejlesztés 1960-as évekbeli első hullámát idézi, amikor is központilag irányított helyi beavatkozások történtek, melyek iparfejlesztésre, különféle létesítmények és infrastrukturális hálózatok létrehozására irányultak, hiányzott belőlük a stratégiai szemlélet. Lux (2019) elemzésében rámutat arra, hogy a Magyarország által a 2000-es évek végén megszenvedett globális gazdasági és pénzügyi válság hatásaként a főáramú fejlesztéspolitikák vélt vagy valós kudarca következett be; ezáltal egy erős állami fejlesztéspolitikához visszanyúló developmentalista fordulat volt megfigyelhető. A Magyarországot ma jellemző városés iparfejlesztési politika elsősorban az 1960-as, 1980-as évek nyugat-európai fejlesztéspolitikája modern tükörképeként értelmezhető, különösen emlékeztet a francia etatizmus-dirigizmus időszakának eszközeire (a gyakorlatban a nemzetállami és a helyi szint tervszerződésekbe foglalja a központi kormányzat finanszírozásával megvalósuló helyi projekteket). Faragó (2018) a Modern városok program előképét szintén Franciaországból eredezteti, hiszen az Magyarországhoz hasonlóan centralizált államszervezettel és elaprózott önkormányzati struktúrával rendelkezik. Ugyanakkor az előképekért szerinte mindössze az ezredfordulóig szükséges visszamenni: az akkor létrehozott városügyi minisztérium koordinálásával a kormányzat tervszerződéseket kötött a kiválasztott városokkal azok fejlesztésére. A minisztérium kötelezően előírta, hogy program megvalósításába a települések vonják be a helyi partnereket, piaci és civil szereplőket. Fentiek alapján hangsúlyozni érdemes, hogy a program hazai előképét nem találtuk a vizsgálat során, az európai hatások közül pedig erőteljesen jelentek meg a francia etetista-dirigista megközelítés attribútumai (tervszerződések, központosított fejlesztéspolitika). 


\section{A Modern városok program finanszírozási kérdései}

A Modern városok program a maga 3400 milliárd forintos nagyságrendjével a valaha volt legnagyobb városfejlesztési program hazánkban, így indokolt annak finanszírozási kérdéseivel is foglalkozni. Mindenekelőtt érdemes hangsúlyozni, hogy 1990 után az önkormányzatok - és ez alól a megyei jogú városok sem voltak kivételek - szembesültek az egyre több, a nemzetállami szint által rájuk testált feladattal, melyekhez nem kaptak megfelelő költségvetési forrásokat, s ez az önkormányzatok nagy részének eladósodásához vezetett. A feladatellátás finanszírozásának megteremtésén túl egyes önkormányzatok a 2000-es évek közepétől rendelkezésükre álló európai uniós fejlesztési források önrészéhez is hitelfelvételre, kötvénykibocsátásra kényszerültek. Különösen megugrott az önkormányzati adósságállomány 2007 és 2010 között: 491 milliárd Ft-ról 1247 milliárd Ft-ra nőtt, ami sok településen erőn felüli adósságszolgálatot eredményezett (Lentner 2014; Novoszáth, Hegedűs 2018a).

2010 után az új önkormányzati törvény új alapokra helyezte az állam és az önkormányzatok közötti feladatmegosztást (2011. évi CLXXXIX. törvény Magyarország helyi önkormányzatairól). A törvény létrehozta a kormányhivatalokat és a járási hivatalokat, melyek számos közigazgatási feladat ellátását átvették az önkormányzatoktól. Ezzel párhuzamosan a közoktatási rendszerben is jelentős változások zajlottak, hiszen az állam átvállalta a közoktatási intézmények fenntartását és működtetését, a pedagógusok bérezését, így az oktatással összefüggő feladatok közül kizárólag a közétkeztetés maradt a helyi szinteknél (továbbá az óvodai hálózat, melyet egyik feladatellátással kapcsolatos változás sem érintett). Az átalakuló feladatellátást bonyolította, hogy a megyei önkormányzatok fenntartásában működő múzeumok és könyvtárak a megyeszékhely önkormányzatainak fenntartásába kerültek.

Az állam átvállalta továbbá az önkormányzatok adósságát, ezzel párhuzamosan megszüntette a személyi jövedelemadó önkormányzati részesedését, az illetékek sem maradtak helyben és a gépjárműadóból befolyó összeg 60\%-a is az állami költségvetésbe folyt be. A megyei jogú városokban a teljes adósságkonszolidáció meghaladta a 370 milliárd Ft-ot. Szintén megszűnt a "gazdag” önkormányzatokat sújtó adóerő-képesség miatti elvonás, vagyis nem büntette a rendszer a nagy adóbevétellel rendelkező önkormányzatokat. Ezzel párhuzamosan bevezették a szolidaritási adót, melyet a befolyt adók mértékével arányosan vetnek ki, s ez a néhány kiemelkedő adóbevételü település esetében rendkívüli mértékü új teherként jelentkezett (Fekete 2017a).

A megyei jogú városok finanszírozása tehát jelentős változásokon ment keresztül az új önkormányzati törvény elfogadását követően. A kutatás nem vizsgálta, hogy a jelenlegi rendszer előnyösebb vagy hátrányosabb-e a megyei jogú városokra nézve - több elemzés és kutatás foglalkozott ezzel az elmúlt időszakban (Pálné Kovács 2016a, 2016b) -, azonban kijelenthető, hogy az adósságkonszolidáció sok város esetében egy „kis Modern városok programként” értelmezheto, hi- 
szen a konszolidált adósság nagyságrendje egyes városoknál a fejlesztési projektcsomag egy városra vetített átlagos értékének $10-30 \%$-át is elérte. ${ }^{3} \mathrm{~A}$ megyei jogú városok jelenleg saját bevételeiken túl fejlesztéseket döntő részben a Modern városok programból, továbbá a Terület- és településfejlesztési operatív programban (TOP) szereplő dedikált kereteikből tudnak megvalósítani. Ez utóbbi pénzügyi forrás jócskán meghaladja a 400 milliárd Ft-ot (Fekete 2017a). ${ }^{4}$

Az egyes városokban a megállapodások 2015 és 2017 között folyamatosan születtek (1. táblázat), az abban foglalt fejlesztések pedig - általában néhány héttel az aláírás után - kormányhatározatokba foglaltattak és kihirdetésre kerültek a Magyar Közlönyben. A fejlesztések felelőseit is megnevezték a kormányhatározatokban, általában konkrét határidők rögzítésével.

A program bekerülési összköltsége hazánk éves költségvetési föösszegének mintegy hatodát teszi ki, de a forrásigény nyilvánvalóan nem egy esztendőben, hanem több évre elnyújtva jelentkezik. A központi költségvetés a program

1. táblázat: A megyei jogú városokkal kötött megállapodások és kormányhatározatba foglalásuk kronológiája

List of agreements with cities with county rights and the chronology of the related government decisions

\begin{tabular}{|c|c|c|}
\hline Megyei jogú város & $\begin{array}{l}\text { Együttmüködési megállapodás } \\
\text { megkötésének időpontja }\end{array}$ & $\begin{array}{l}\text { Kormányhatározat száma (Magyar } \\
\text { Közlönyben való megjelenés dátuma) }\end{array}$ \\
\hline Békéscsaba & 2016. április 26. & 1283/2016. (VI. 7.) \\
\hline Debrecen & 2015. május 18. & 1382/2015. (VI. 12.) \\
\hline Dunaújváros & 2016. május 31. & 1394/2016. (VII. 21.) \\
\hline Eger & 2015. április 10. & 1251/2015. (IV. 23.) \\
\hline Érd & 2015. július 3. & 1504/2015. (VII. 23.) \\
\hline Győr & 2017. április 28. & 1387/2017. (VI. 27.) \\
\hline Hódmezővásárhely & 2017. május 26. & 1840/2017. (XI. 10.) \\
\hline Kaposvár & 2015. október 9 . & 1803/2015. (XI. 10.) \\
\hline Kecskemét & 2016. február 9. & 1131/2016. (III. 10.) \\
\hline Miskolc & 2016. február 11. & 1315/2015. (V. 21.) \\
\hline Nagykanizsa & 2015. június 23. & 1496/2015. (VII. 21.) \\
\hline Nyíregyháza & 2015. november 10 . & 1955/2015. (XII. 17.) \\
\hline Pécs & 2015. április 28. & 1316/2015. (V. 21.) \\
\hline Salgótarján & 2017. március 21. & 1388/2017. (VI. 27.) \\
\hline Sopron & 2015. március 24. & 1217/2015. (IV. 17.) \\
\hline Szeged & 2017. január 30. & 1151/2017. (III. 20.) \\
\hline Székesfehérvár & 2015. május 26. & 1383/2015. (VI. 12.) \\
\hline Szekszárd & 2016. február 23. & 1159/2016. (IV. 5.) \\
\hline Szolnok & 2015. június 3. & 1428/2015. (VI. 25.) \\
\hline Szombathely & 2015. november 17 . & 1936/2015. (XII. 12.) \\
\hline Tatabánya & 2016. március 22. & 1240/2016. (V. 13.) \\
\hline Veszprém & 2016. május 10. & 1284/2016. (VI. 7.) \\
\hline Zalaegerszeg & 2015. április 14 . & 1252/2015. (IV. 23.) \\
\hline
\end{tabular}


megvalósítására 2015-ben 25, 2016-ban 50, 2017-ben 152, 2018-ban 150 milliárd Ft-ot tartalmazott, az elfogadott 2019-es büdzsé 135 milliárd Ft-ot irányzott elö, hangsúlyozva, hogy ez a közúti fejlesztések nélkül értendő. A beruházások intenzíven a 2017-es évben indultak meg, így a 2017-es és 2018-as adatokból már érdemes néhány arányszámot megadni. A központi költségvetés felhalmozási célra tervezett összegeinek 2017-ben 8,71\%-át, 2018-ban pedig 8,33\%-át irányozták elő a program megvalósítására (ez csak a hazai forrás és nem tartalmazza az európai uniós támogatású operatív programokból finanszírozott beruházásokat). Az előirányzat 2017-ben a GDP 0,41\%-át, 2018-ban pedig 0,37\%-át teszi ki (Novoszáth, Hegedűs 2018b). Fenti adatok alapján elmondható, hogy nem helytállók azok a vélemények, melyek szerint a program finanszírozása ne lenne biztosított annak aránytalanul nagy mivolta miatt. Feltételezhető, hogy a projektek hozzávetőleg felét az operatív programokból finanszírozzák, melyek 2022-ig mindenképp lezárulnak, így a központi költségvetésből 2019-2023 között évi 265 milliárd Ft-ból a program megvalósítása pénzügyi szempontból biztosított lehet. ${ }^{5}$ Jelen költségvetési viszonyok mellett ez az összeg nem jelent aránytalanul nagy terhet a központi költségvetés számára.

A program kezdetén a kormány alapvetően hazai forrásból kívánta előteremteni a szükséges pénzügyi forrásokat, kivéve azon nagy volumenű közlekedésfejlesztési projekteket, melyek eleve szerepeltek az Integrált közlekedésfejlesztési operatív programban (IKOP). Másfél évvel a program elindítása után, 2016 júliusában ugyanakkor változás történt: egy új kormányrendelet értelmében a programban szereplő fejlesztéseket elsődlegesen európai uniós források felhasználásával kell megvalósítani, így az önkormányzatok arra kényszerültek, hogy a TOP-os fejlesztési kereteikből „áldozzanak” a Modern városok programban szereplö fejlesztésekre - igaz, a kormány sok város esetében a keretek megemelése mellett határozott. A 2017-ben kötött megállapodások fedezetéül ugyanakkor már újból a hazai forrásokat nevezték meg, hiszen addigra az érintett önkormányzatok TOPkeretük nagy részét lekötötték (Fekete 2017a).

\section{A program szerkezete, kapcsolódási pontjai az európai tér gazdaságfejlesztési és újraiparosítási folyamataihoz}

A megyei jogú városokkal kötött megállapodások preambulumában - mely minden város esetében azonos szövegezésü - az alábbiakat olvashatjuk: „A megállapodások célja, hogy ezek a büszke városok a 21. század nyertesei, a magyar vidék fejlődésének zászlóshajói legyenek, és a jövőben a legmodernebb és a legsikeresebb európai városok közé tartozzanak. Nekünk, magyaroknak a modern város a magyar várost jelenti, amit a magyar temperamentum és észjárás alakít. Otthonos és családias közösséget, biztonságos környezetet, ahol van munkalehetőség, javulnak az életkörülmények, (...) ahol szépülnek az utcák, a 
terek, az épületek, ahol pezseg az élet." A preambulumban tehát általános jövőképet vázoltak fel a megyei jogú városok számára, melynek megvalósításához a program különböző projekteken keresztül kíván hozzájárulni.

Érdemes a projekteket különféle kategóriákba sorolni. Gulyás (2017) összegzése nyomán (2. táblázat) elmondható, hogy a program közlekedésfejlesztési fókusszal bír. Az országos közútfejlesztések a projekt költségvetésének 56\%-át jelentik, s amennyiben ide soroljuk a kapcsolódó projekteket (intermodális csomópontok, helyi utak, kerékpárutak, repülőterek fejlesztése, helyi közösségi közlekedés, repülőterek modernizálása), úgy az arány megközelíti a 70\%-ot. A városi infrastruktúra fejlesztésére, városrehabilitációs célokra, továbbá kulturális és turisztikai célokra a program 12\%-át kívánják fordítani, egészségügyre és sportra pedig 7\%-ot.

Gazdaságfejlesztésre és innovációra (ideértve az ipari parkok fejlesztését és az oktatás, szakképzés területén beharangozott fejlesztéseket) a program több mint 400 milliárd Ft-ot fordít, a Modern városok program költségvetésének mintegy 12\%-át. Emellett a közlekedésfejlesztési elemek is kapcsolódnak a gazdaságfejlesztési és innovációs folyamatokhoz.

2. táblázat: A Modern városok program projektjei fóbb fejlesztési kategóriánként Projects of Modern Cities Programme by main development categories

\begin{tabular}{llc}
\hline \multicolumn{1}{c}{ A fejlesztések fóbb típusai } & \multicolumn{1}{c}{$\begin{array}{c}\text { A fejlesztés } \\
\text { gyakorisága }\end{array}$} & $\begin{array}{c}\text { Becsült költség } \\
\text { (milliárd Ft) }\end{array}$ \\
\hline 1. Országos közútfejlesztések & 21 fejlesztés, $690 \mathrm{~km}$ & 1920,699 \\
2. Intermodális csomópontok kialakítása & 9 városban & 107,842 \\
3. Helyi útfejlesztések & 11 várost érintően & 92,091 \\
4. A helyi közösségi közlekedés fejlesztése & 7 városban & 28,920 \\
5. Vasútfejlesztés & 3 városban & 176,100 \\
6. Repülőterek fejlesztése & 5 városban & 14,727 \\
7. Kerékpárút-fejlesztések & 7 városban & 23,038 \\
8. Várfelújítások, műemléképületek felújítása & 5 városban & 28,010 \\
9. Kulturális fejlesztések & 17 beruházás & 80,017 \\
10. Turisztikai fejlesztések & 23 városban & 169,448 \\
11. Iparipark-fejlesztések & 20 városban & 137,696 \\
12. Gazdaságfejlesztések és innovációs projektek & 21 városban & 167,209 \\
13. Oktatási, szakképzési fejlesztések & 22 fejlesztés & 109,219 \\
14. Egészségügyi fejlesztések & 5 városban & 19,384 \\
15. Sportfejlesztések & 32 beruházás & 151,272 \\
16. Közmú- és energetikai fejlesztések & 8 városban & 87,539 \\
17. Városrehabilitáció, városi lakókörnyezet-fejlesztések & 16 beruházás & 47,170 \\
18. Egyéb fejlesztések & 29 projekt & 27,736 \\
\hline A fejlesztések teljes becsült forrásigénye & & 3388,716 \\
\hline
\end{tabular}

Forrás: Gulyás (2017). 
Bajmócy (2018) tanulmányában a Modern városok programot vizsgálja a helyi gazdaságfejlesztés szemszögéből. A normatív keretben (mely a növekedésből indul ki) a stratégiák olyan eszközöket kívánnak létrehozni, melyeket a helyben élők jólétük növelésére tudnak fordítani, míg a ,jóllét” összetevőiből kiinduló megközelítések arra fókuszálnak, hogy a helyi közösség a lehető legszélesebb körben részt vegyen a megalapozó stratégiák és kapcsolódó célok kidolgozásában, s ezáltal biztosított legyen a létrehozni kívánt eszközök kompatibilitása és hozzáférhetősége. A Modern városok program célrendszerét (1. ábra) elemezve Bajmócy arra a következtetésre jut, hogy a megjelenő projektek gyakorlatilag mindegyike építési projekt, vagyis a normatív megközelítést követi a program filozófiája, s emiatt véleménye szerint a jóllétből kiinduló megközelítés szempontjából kérdéses a program hatékonysága. Faragó (2018) a városrezsim-típusú együttmüködések szemszögéből szintén rámutat a helyi szereplők széles körű bevonásának szükségességére - illetve véleménye szerint annak elmaradására a program kidolgozása során.

A Modern városok programot jelentős, az újraiparosításra irányuló gazdaságfejlesztési törekvés hatja át, hiszen 17 város érintett ipari park fejlesztésében, továbbá ezzel rokon eszközök (logisztikai központ, inkubátorház) tele-

1. ábra: A Modern városok program tartalomelemzés alapján rekonstruált célrendszere objectives of the Modern Cities Programme as reconstructed by the content analysis)

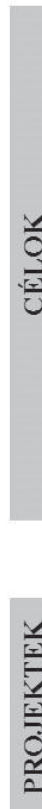

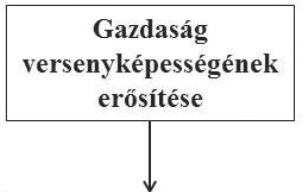

1. Munkahelyteremtés

2. Iparfejlesztés

3. Turisztikai vonzerô növelése

4. Humán erőforrás képzettségének javítása

5. Város elérhetőségének javítása
1. Közösségi és sportélet támogatása 2. Kulturális és lelki élet fellendítése 3. Lakókörnyezet fejlesztése

4. Közszolgáltatások minőségének javítása

5. Városi (közlekedési) infrastruktúra javítása

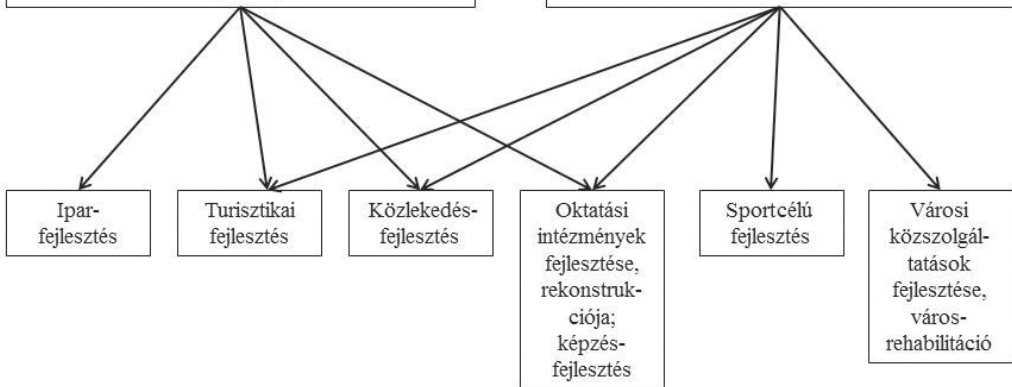

Forrás: Bajmócy (2018). 
pítésében, és több helyen a hagyományos iparágak (pl. üveggyártás, nyomdaipar) újjáélesztése, fejlesztése is szerepel a megállapodásokban. Az iparág-specifikus fejlesztések komoly jelentőségűek az adott város életében, hiszen a helyi termelési hagyományok megújításával újrafogalmazhatók a meglévő ipari fejlődési pályák (Bajmócy 2018; Lux 2019).

Lux (2019) hangsúlyozza, hogy noha a Modern városok program nem célzottan újraiparosítási program, mégis mind a 23 érintett városban megvalósulnak az iparfejlesztést közvetlenül vagy közvetve segítő beruházások. Elemzése szerint a program keretében 77 projekt iparpolitikai érintettségü, melyből 30 közlekedésfejlesztési, 26 iparfejlesztési, 16 szakképzéshez, oktatáshoz és K+F-hez, 4 az elektromos tömegközlekedés megteremtéséhez kapcsolódik, míg egyedüliként Kecskeméten egy speciális pénzalap megteremtésére is lehetőség nyílik.

Az újraiparosítási folyamatokat kiemelten segítik azok a közlekedésfejlesztési elképzelések, melyek a megyei jogú városokat bekapcsolják az országos autópálya-hálózatba, gyorsforgalmi kapcsolatokat eredményeznek határon túli gazdasági központok irányába (pl. Miskolc-Kassa, Győr-Dunaszerdahely). Emellett a városi elkerülő utak megépítése azon túl, hogy élhetőbbé teszi a városok belső részeit a csökkenő forgalom következtében, javítja a meglévő ipari parkok elérhetőségét és feltárja a logisztikai funkciók telepítésére alkalmas területeket (Lux 2019).

Mindezek alapján az újraiparosítás közvetlen és közvetett módszereit is alkalmazza a Modern városok program, a telephelyek fejlesztése mellett a tudásbázis erősítésének szándéka is megjelenik a fejlesztésekben.

\section{Vitapontok}

A kutatási program során történt kutatói eszmecserék révén üdvözlendő tudományos diskurzus alakult ki, melynek néhány fontosabb elemét az alábbiakban röviden közzéteszem, hangsúlyozva, hogy napjaink területfejlesztési folyamatainak közös értékelése, a vélemények ütköztetése fontos feladata a hazai regionális tudományok művelőinek. A programot több kritika is elmarasztalta a társadalmi bekapcsolódás elmaradása miatt. Faragó (2018) szerint a program azért nem új városrezsim, mert nem széles résztvevői körrel állították azt össze. Bajmócy (2018) a program hátrányaként értékeli a központi döntéshozatalt, véleménye szerint a megállapodásokba bekerült projektek nem kapcsolódnak helyben széles körben egyeztetett stratégiákhoz, erre utal a projektek hasonló (one-size-fits-all) mivolta. Ugyanígy kevésnek érzi az önkormányzatok bekapcsolódását a központi döntéshozatalba, szerinte a helyi fejlesztéssel kapcsolatos döntéshozatal nem a helyi, hanem az országos szinten történt. Több kutató szerint alapvető probléma, hogy a Modern városok program nem rendelkezik átfogó stratégiával, stratégiai szemlélettel, nincs kapcsolódási pontja „nagyobb egészhez”. 
Véleményem szerint a 2000-es években a nagyvárosok mindegyikében elkészültek azok a stratégiai dokumentumok (pl. integrált városfejlesztési stratégia, integrált településfejlesztési stratégia, településfejlesztési koncepció), melyek kiforrott célok mentén fogalmazzák meg a jövőbeli fejlesztési elképzeléseket, s ezekben a koncepció-stratégia-projekt lebontását alkalmazó, koherens anyagokkal találkozhatunk. A kritikákra reagálva a kutatás során egy kiválasztott várost (Győr) esettanulmányszerüen megvizsgáltam. Valamennyi, a Modern városok program által Győrben megvalósítandó fejlesztés kapcsolódik a város jövőképében foglalt célkitűzésekhez, döntő többsége közvetlenül is hozzárendelhető azokhoz (Fekete 2018a). Mélyebb vizsgálatokra lenne szükség ahhoz, hogy a városok stratégiaalkotási folyamataiba vajon sikerült-e bekapcsolni a stakeholderek igényeit, és ha igen, milyen mértékben. A győri példa és a stratégiai dokumentumok alapján magam nem rovom fel a program kritikájaként, hogy a megállapodások megkötése elött nem volt kifejezetten a Modern városok programra irányuló igényfelmérés - feltételezve, hogy a városok a stratégiaalkotás folyamán megfelelően becsatornázták és a városi érintettekkel (civil szervezetek, gazdasági szereplők, egyházak stb.) közösen fogalmazták meg a stratégiai célokat, és a városvezetők azok mentén állították össze a kormányfö elé tárt „kívánságlistájukat”.

Az újraiparosítási folyamatok szempontjából Lux (2019) szerint a legnagyobb nyertesek a Dél-Alföld városai, ahol megfigyelhető a koherens víziók és a projekteszközök egysége, míg a Dunántúl erősen iparosodott városaiban föként a kiegészítő jellegü, tudásbázist erősítő elemek a fontosak. Noha valóban jelentős szerepet játszik a térségek fejlődésében e régiók tudásbázisát erősítő helyi fejlesztések megvalósítása, azt is érdemes hangsúlyozni, hogy ezeken a területeken az alap-infrastruktúra sok esetben nem áll rendelkezésre magas színvonalon, a fejlesztéseknek így a 21. századi tudásgazdaság és egyéb, jövőbe mutató irányzatok erősítése mellett épp a legiparosodottabb területeken szükséges olyan klasszikus infrastruktúra-fejlesztési beruházásokra fókuszálniuk, mint például az elkerülő utak építése. Emiatt tűnhet egy kaptafára készült programnak a fejlesztéscsomag, de ezeken a területeken is a valós igényekre reflektál, hiszen több vizsgálat is rámutatott arra az elmúlt években, hogy pl. az országos közúthálózat legrosszabb állapotban lévő elemei Győr-Moson-Sopron megyében találhatók. ${ }^{6}$

Noha a Modern városok program korábban nem látott fejlesztési csomagként segítheti a hazai legnagyobb települések modernizációját, Rechnitzer (2019) szerint ez önmagában nem eredményezi majd hazánk föváros-centrikusságának oldódását, hiszen az érintett városok nem kapnak ehhez szükséges autonómiát. A cikk elején utaltam rá, hogy a hazai településhálózat aránytalanságáért legfóképpen a trianoni döntést, majd a Nagy-Budapest koncepciót tehetjük felelőssé. Magam is azon a véleményen vagyok, hogy önmagában a Modern városok program végrehajtása nem fogja oldani a fövárosi túlsúlyt, azonban a hazánkban tapasztalható népességfogyással párhuzamosan katalizálhatja az egyre élhetőbb me- 
gyei jogú városokba való betelepülést, ami növelheti a kiemelt városok súlyát a településhálózaton belül.

\section{Kitekintés, javaslatok}

A kutatás eredményeinek ismeretében elmondható, hogy a hazai területfejlesztés elmúlt évszázadában nem találtunk olyan városfejlesztési programot, mely filozófiájában és költségvetési volumenében hasonlítható lenne a Modern városok programhoz. A program előképeit elsősorban az 1960-as években megjelenő, de napjainkban is gyakran alkalmazott francia etatista-dirigista megközelítésekben fedeztük fel, hiszen jelentős hasonlóságot mutatnak az alkalmazott eszközök és módszerek, így például a tervszerződések rendszere, a központi finanszírozás és döntéshozatal. A program ugyanakkor nem értelmezhető újszerü városfejlesztési rezsimként: a program kialakításába nem vonták be széles körűen a társadalmat, a fejlesztési célkitűzéseket nem közösen alakították ki. Mindez nem jelenti azt, hogy a városokban végrehajtandó projektek ne találkoznának a városalakító közösségek valós igényeivel: a fejlesztési csomagok több esetben a megfelelő társadalmi előkészítéssel létrehozott városi stratégiákon alapulnak.

Világossá vált, hogy a megyei jogú városokat érintő kormányzati döntések közül a program meghatározó fejlesztési forrásokat biztosít az érintettek számára, városonként átlagosan kb. 150 milliárd Ft értékben. A 3400 milliárd Ft-os programmal párhuzamosan a TOP-os hozzávetőleg 400 milliárd forintnyi összeg további vagy kapcsolódó fejlesztések fedezetét biztosítja, s érdemes megemlíteni, hogy a 23 megyei jogú városban a kormány által konszolidált adósság volumene nagyságrendileg megegyezik az operatív program városfejlesztési forrásainak nagyságával. Mindezek ismeretében a megyei jogú városokat a kormányzat jelentősen támogatja.

A program közlekedésfejlesztési fókusszal rendelkezik, a források mintegy 70\%-át e célra allokálja. Hangsúlyozni érdemes, hogy sok helyen az alap-infrastruktúra kiépítése történik meg ezáltal, de a közútfejlesztések potenciális gazdasági területeket is feltárnak és a közösségi közlekedés is fejlődik (pl. az elektromos buszok beszerzésének támogatása, kerékpárút-építések, a vasúti közlekedés modernizációja). Ezen intézkedésekkel erősödhet a városok térségszervező szerepe, javulhat a térségi funkciók elérésének minősége. Gyakorlatilag valamennyi város érintett az iparfejlesztési, gazdaságfejlesztési intézkedésekben, ezek valós hasznosulásának mértéke ugyanakkor megosztotta az elemzőket. Mindenestre a nevesített projektek az egyes városok megközelíthetőségének és belső közlekedési viszonyainak javítására, gazdasági és munkahely-teremtési célkitűzéseinek segítésére, továbbá élhetőségük javítására fókuszálnak. 
2017-ben új, a megyei jogú városok fejlesztéséért felelős tárca nélküli miniszter kezdte meg működését, kiemelt fókusszal a Modern városok programmal kapcsolatok koordináció ellátására. Ezt követően pozitív változások történtek több városfejlesztési projektben: kormányhatározatokat módosítottak annak érdekében, hogy a fejlesztési források felhasználása, a projektek megvalósítása ne az állami központi szerv (zömmel a Magyar Nemzeti Vagyonkezelő Zrt.), hanem az érintett önkormányzat feladata legyen (Magyarország kormánya 2017). Ez mindenképpen üdvözlendő irány, hiszen az önkormányzatok helyismeretük, beruházások megvalósításában szerzett tapasztalatuk alapján alkalmasak a projektek végrehajtására - ráadásul újabb lehetőség nyílik a helyi szint bekapcsolódására a megvalósítás során. A 2018-as választásokat követően a Modern városok program koordinációja továbbra is a Miniszterelnökségen belül, ám nem tárca nélküli miniszteri szinten, hanem kormánybiztos irányítása alatt folytatódott. A kormánybiztos a Modern falvak és kisvárosok program kidolgozásáért és végrehajtásáért is felel.

A Modern városok program megvalósításának elindulását követően egyre többször lehetett olyan kormányzati szándékról hallani, mely a hazai középvárosok fejlesztésének programjáról szólt, a megyei jogú városokéhoz hasonló konstrukcióban. 2018 februárjában a kormányfö a Megyei Jogú Városok Szövetsége ülésén jelentette be, hogy hamarosan indulhat a középvárosok fejlesztési programja, melyet a kistelepülések követhetnek. A kormányzati településfejlesztési elképzelések tehát nem zárultak le a 23 megyei jogú város programjával, hanem a településhierarchia alsóbb szintjeit is külön programokban kívánják bekapcsolni a települési infrastruktúra-fejlesztési folyamatokba. Egyetértek Faragó (2018) megállapításával, miszerint érdemes lenne új településhálózat-fejlesztési stratégiát alkotni annak érdekében, hogy a program(ok) koherens célkitűzések megvalósulását szolgálhassák. Ugyanakkor a Modern városok program és a középvárosok fejlesztésének kormányzati szándéka ismeretében egyértelmủ a városok kiemelt szerepe napjaink hazai területpolitikai döntéseiben.

A kutatást a jövőben több vizsgálati szempont beemelésével célszerűnek tartom tovább folytatni. Érdemes lenne városonkénti összehasonlító vizsgálatot végezni, mely alapján csoportok képzésére is lehetőség nyílna a városok között aszerint, hogy a Modern városok programban szereplő fejlesztések mire fókuszálnak, mit tartottak hangsúlyosnak, milyen ütemben zajlik a megvalósítás stb. Szintén további vizsgálati dimenziót jelenthet a megvalósult fejlesztések feltérképezése, 2021-2022 körül a program eredményességének vizsgálata (pl. a projektek hogyan hatottak az egyes városok teljesítményére, versenyképességére, továbbá a program költségvetése hogyan változott). A program zárásával párhuzamosan tehát ex post értékelés elvégzése tűnik indokoltnak, előzetesen kidolgozott módszertan és szempontrendszer szerint. 


\section{Jegyzetek}

1 A kutatás vezetője: Fekete Dávid, a kutatásban részt vettek: Rechnitzer János, Bajmócy Zoltán, Faragó László, Lux Gábor, Hegedűs Szilárd, Novoszáth Péter.

2 A cikk korábbi változatának lektorai hiányolták a „saját hang” és a saját kutatási eredmények hangsúlyosabb megjelenítését. Jelen cikk célja ugyanakkor, hogy a kutatás során feltárt legfontosabb megállapításokat összegezze és rendszerezze. Saját győri empirikus kutatásaimmal kapcsolatban lásd Fekete (2018a), a kutatásindító koncepció, tematika lényegi elemeiről lásd Fekete (2017a). A kutatási eredmények értékelését, személyes véleménnyel kiegészítve e cikk Vitapontok része tartalmazza.

3 A 3400 milliárd Ft-os fejlesztési csomag egy városra vetített átlagos költsége megközelítőleg 147 milliárd Ft. Pécs esetében a konszolidált önkormányzati adósság meghaladja ezen összeg 30\%-át, Miskolc esetében 25\%, Debrecennél közel 20\% ez az arány.

4 Ráadásul ez a keret nem tartalmazza Érd megyei jogú város forrásait, hiszen a város nem a TOP-ból, hanem a VEKOP-ból juthat pénzügyi támogatáshoz.

5 Az 50\%-os arány bizonyításához pontos adatok nem állnak rendelkezésre, ugyanakkor az érintett városok több mint fele fejlesztéseinek jelentős részét a TOP-os (gyakran megemelt) keretéből finanszírozza, míg a program keretének több mint felét jelentő közlekedésfejlesztési beruházások nagy részét az IKOP-ból finanszírozzák. Figyelemmel kell lenni arra, hogy a 2022-es befejezést nyilvánvalóan veszélyeztetheti a mindenkori költségvetési források mértéke, illetve az egyes fejlesztések jelentős időigényű előkészítése, tervezése, engedélyezése.

6 De ide sorolhatjuk azt a tényt is, hogy a magyar nagyvárosok közül talán utolsóként kezdődött meg Győr körül az elkerülő út építése, mely a Modern városok programban szereplő északnyugati rész megépítésével válhat egyszer teljessé. Érdemes megemlíteni azt is, hogy az M1-es autópálya kapacitása kisebb a tényleges szükségletnél: 2018 januárjában hosszú szakaszokon 80 km/órás sebességkorlátozást kellett bevezetni a burkolat rendkívül rossz állapota miatt. Noha elindult az autópálya $2 \times 3$ sávossá bővítésének tervezése, belátható időn belül nem várható a zsúfoltság érdemi enyhítése.

\section{Köszönetnyilvánítás}

A kutatás a Gróf Bethlen István Kutatóközpont „Modern városok Magyarországon” c. kutatási programja keretében valósult meg.

\section{Irodalom}

2011. évi CLXXXIX. törvény Magyarország helyi önkormányzatairól. https://net.jogtar.hu/jogszabaly? docid=A1100189.TV (Letöltés: 2019. január 14.)

Bajmócy Z. (2018): Időutazás a Modern városok programmal. Értékelés helyi gazdaságfejlesztési szemszögból. Kézirat

Bajmócy Z., Gébert J., Elekes Z., Páli-Dombi J. (2016): Beszélünk a részvételről... Megyei jogú városok fejlesztési dokumentumainak elemzése az érintettek részvételének aspektusából. Tér és Társadalom, 2., 45-61. http://doi.org/cz96

Bajmócy Z., Gébert J., Málovics Gy. (szerk.) (2017): Helyi gazdaságfejlesztés a képességszemlélet alapján. JATEPress, Szeged 
Barta Gy., Czirfusz M., Kukely Gy. (2008): Újraiparosodás a nagyvilágban és Magyarországon. Tér és Társadalom, 4., 1-20. http://doi.org/czm6

Enyedi Gy. (2012): Városi világ. Akadémiai Kiadó, Budapest

Faragó L. (2006): A városokra alapozott területpolitika koncepcionális megalapozása. Tér és Társadalom, 2., 83-102. http://doi.org/czm7

Faragó L. (2016): Az EU területi politikájának a változásai közép-kelet-európai nézőpontból. Tér és Társadalom, 2., 3-22. http://doi.org/bsnm

Faragó L. (2018): A Modern városok program mint fejlesztéspolitikai rezsim helye a magyar területfejlesztési politikákban. Kézirat

Fekete D. (2017a): A Modern városok program elemzési lehetőségei. Polgári Szemle, 1-3., 94-105. http://doi.org/czk9

Fekete D. (2017b): Európai jármüipari térségek gazdasági kormányzási modelljei. Tér és Társadalom, 3., 125-142. http://doi.org/czm8

Fekete D. (2018a): A Modern városok program győri fejlesztései. Területi Statisztika, 6., 638-658. http://doi.org/czm9

Fekete D. (2018b): Economic development and economic governance through the example of the city of Győr. Deturope, 1., 97-115.

Füzér K. (2017): A projektesitett város: Részvételi városfejlesztés az ezredfordulós Pécsett. Publikon Kiadó, Pécs

Gulyás I. (2017): Modern városok program. Deloitte, Budapest

Hajdú Z. (1993): A terület- és településfejlesztés problematikája a két világháború között. In: Kovács K. (szerk.): Település, gazdaság, igazgatás a térben. MTA RKK, Pécs, 19-34.

Hajdú Z. (2001): Magyarország közigazgatási földrajza. Dialóg Campus Kiadó, Budapest, Pécs

Lengyel I. (2010): Regionális gazdaságfejlesztés. Versenyképesség, klaszterek és az alulról szerveződő stratégiák. Akadémiai Kiadó, Budapest

Lentner Cs. (2014): A magyar önkormányzatok adósságkonszolidációja. Pénzügyi Szemle/Public Finance Quarterly, 3., 330-344.

Lux G. (2017): Újraiparosodás Közép-Európában. Dialóg Campus Kiadó, Budapest, Pécs

Lux G. (2019): A Modern városok program újraiparosítási törekvései. Tér és Társadalom, 1., 44-65. https://doi.org/10.17649/TET.33.1.3067

Magyarország kormánya (2017): A Modern városok programban nagyobb szerepet kapnak az önkormányzatok. http://www.kormany.hu/hu/tarca-nelkuli-miniszter-2/hirek/a-modern-varosok-programbannagyobb-szerepet-kapnak-az-onkormanyzatok (Letöltés: 2019. január 14.)

Mezei, C. (2016): Limited involvement: the role of local and regional actors in the Hungarian Structural Fund management In: Schmitt P., Van Well, L. (eds.): Territorial governance across Europe: Pathways, practices and prospects. Routledge, London, New York, 157-170.

Novoszáth P., Hegedűs Sz. (2018a): A megyei jogú városok a kormányzati pénzügypolitikában. Kézirat Novoszáth P., Hegedűs Sz. (2018b): A Modern városok program költségvetési forrásainak vizsgálata. Kézirat

Pálné Kovács I. (2010): Városi terek kormányzása és a városi rezsimek. Egy induló kutatás margójára. Tér és Társadalom, 4., 3-27. http://doi.org/cznb

Pálné Kovács I. (2016a): A magyar területi közigazgatási reformok főbb állomásai. In: Pálné Kovács I. (szerk.): A magyar decentralizáció kudarca nyomában. Dialóg Campus Kiadó, Budapest, Pécs, 73-85.

Pálné Kovács I. (2016b): Záró gondolatok. In: Pálné Kovács I. (szerk.): A magyar decentralizáció kudarca nyomában. Dialóg Campus Kiadó, Budapest, Pécs, 200-206.

Pálné Kovács I., Mezei C. (2016): Regionális politikai és területi kormányzási ciklusok Közép- és Kelet-Európában. Tér és Társadalom, 4., 54-70. http://doi.org/crtw

Rechnitzer J. (2019): Nagyvárosok a magyar területi politikában és területfejlesztésben a rendszerváltozástól napjainkig. Tér és Társadalom, 1., 3-26. https://doi.org/10.17649/TET.33.1.3069

Somlyódyné Pfeil E. (2011): Az agglomerációk jelentőségének változása az államszervezés és a városi kormányzás szempontjából. Tér és Társadalom, 3., 27-59. http://doi.org/cznc

Somlyódyné Pfeil E. (2014): Az állam megváltozott szerepe és a városfejlesztés viszonya. Tér és Társadalom, 2., 31-44. http://doi.org/cznd

Stone, C. (1989): Regime politics: Governing Atlanta, 1946-1988. University Press of Kansas, Lawrence

Stone, C., Sanders, H. T. (1987): The politics of urban development. University Press of Kansas, Lawrence 